\title{
The New Jewish Question
}

\section{To the memory of Breonna Taylor and George Floyd, הי"ד}

\author{
Daniel Boyarin \\ University of California Berkeley, Berkeley, USA \\ Email: boyarin@berkeley.edu
}

\begin{abstract}
In this article I attempt to lay out at least the bones of an argument for a shift in the terms of world Jewish life. Against the Hobson's choice of "religion" or "state," I offer an older paradigm of diaspora nation, the Yiddishe Folk. Because I am opposed to both the mononational state and cosmopolitanism (of the classic Appiah-like variety), I work out a description (not fully defined) of diaspora that comprises dual loyalties, to the place where I am and especially its oppressed people and to others of my nation scattered in many places (ideally!). This statement constitutes a vade mecum to a longer manifesto to be published by Yale University Press, late in 2022.
\end{abstract}

Keywords: Jews; anti-Zionism; Négritude/Judaitude; Talmud

In the time of preparation of this article proposing a model for an ethical and vital continuation of the Jews, I have been literally surprised-almost shocked-at a furious response to the project itself that has come from various quarters and in various forms, namely vehement opposition to any meaningful continuation of Jewish collectivity at all. I had expected fury from the right but hardly from the left, and have had to think hard where it comes from. There are, so it seems to me, two basic reasons why people "of good will" continue to think that the Jews should not persist as a collective-even if most of these people do not take the time to articulate to themselves that they do think that, and even if they are unaware of these two reasons. One is the "lingering" and very much still potent doctrine of Christian supersessionism-the idea that with the new revelation, Jewish particularism is now obsolete. This doctrine, as has been shown in various works of postcolonial criticism (e.g., J. Boyarin, A. Mufti, Kathleen Biddick, Kathleen Davis), deeply informs modern colonial ideologies of Eurocentric progressivism. Precisely the fact that it also informs the implicit attitudes of critical people of good will shows how effective it remains. The second is the still potent doctrine that the permits unrestricted re-use, distribution and reproduction, provided the original article is properly cited. 
peoples and land of the world are best and "rightly" divided up into ethnic nationstates. Indeed, much of the animus against the persistence of the Jews as a collective (and endless amounts of confusion) centers around the effort of Jews and others to "solve the Jewish problem" by creating a Jewish nation-state-a solution that has been in many ways disastrous for Jews and for others. In the nineteenth and twentieth centuries, this has often led to the charge that Jews who continue to manifest their distinctive identity, even when they have the opportunity to shed it, are engaging in an unwarranted (and some would suspect, characteristic) chauvinism or clannishness. The effectiveness of these two factors (supersessionism and territorial nationalism) to inform prejudice against collective Jewish continuity is perhaps mitigated when Jews per se are obviously the objects of collective discrimination, and correspondingly exacerbated when Jews as a collective appear to be "powerful" or secure.

Here I propose an argument for an ethical form of Jewish collective continuity. It simply rejects the theology of supersessionism, arguing that there is no reason why Jews have more or less right to collective existence than any other, what I call here, nation-a complex term whose implications I will unpack throughout this article and the book for which it is meant to be a part. For reasons I and others have elaborated elsewhere, I also reject the "Zionist" nationstate solution to Jewish collective continuity in favor of a diasporic nationalism that offers not the promise of security, but rather the highly contingent possibility of an ethical collective existence. As one early anonymous reviewer remarked (generously) of the draft they read: "This piece ... is meant to be a generous invitation to cultural others to imagine themselves as like Jews. I do think the invitation is not so easily accepted because of the specific history of the Jews... . The piece is somewhat prescriptive and focuses on how things ought to be. It is arguing against state Zionism and against assimilation (called cosmopolitanism) but is ultimately an argument made to fellow Jews, yet framed in universal terms so that others can recognize themselves in it." They have caught my intent precisely, more precisely than I could have articulated it.

I do not expect the argument to be welcomed eagerly by all. So be it.

\section{The Coexistence of Them All}

It is possible for white theorists to be influenced by non-white theorists, just as it is possible for non-white theorists to be influenced by white theorists. -Reiland Rabaka

I'm not going to confine myself to some narrow particularism. But I do not intend either to become lost in a disembodied universalism... . I have a different idea of a universal. It is a universal rich with all that is particular, rich with all the particulars there are, the deepening of each particular, the coexistence of them all.

-Aimé Césaire ${ }^{1}$

\footnotetext{
${ }^{1}$ Aimé Césaire, Député for Martinique, to Maurice Thorez, Secretary General of the French Communist Party, October 1956, quoted in Robin D. G. Kelley's introduction to Césaire's Discourse on Colonialism (New York: Monthly Review Press, 2000), 25-26. I found this quotation, which I adopt as my
} 
Césaire here is condemning a certain kind of cosmopolitanism, the kind that seeks to deracinate deep and important differences in Lebensformen between different human groups and somehow always advances a universal morality that is consistent with the mores of the dominant political and ethnic group. Haun Saussy's critique of neoliberal (my term here) cosmopolitanism strikes home indeed. ${ }^{2}$ And I learn from him as well that Césaire's declaration just quoted by me was in a letter responding to a controversy among Sartre, Levi-Strauss, and Fanon, in which Sartre had offered a dialectical image in which the "Negro" and "Négritude" would be sublated (aufgehoben) into the unmarked-for-race working class struggle. ${ }^{3}$ As Saussy determines, "For Frantz Fanon, this scenario of the future Aufhebung (dialectical sublation) of race implied the Aufhebung (cancellation) of his history and identity-a grimly negative reading that saw the cannibal qualities of Sartre's Hegelian optimism." ${ }^{4}$ Upon reading Sartre's declaration in his Black Orpheus that:

In fact, Négritude appears as the weak stage of a dialectical progression: the theoretical and practical affirmation of white supremacy is the thesis; the position of Négritude as antithetical value is the moment of negativity. But this negative moment is not sufficient in itself and the Blacks who employ it well know it; they know that it serves to pave the way for the synthesis or the realization of the human society without race. Thus Négritude is dedicated to its own destruction, it is transition and not result, a means and not the ultimate goal, ${ }^{5}$

Fanon writes, "When I read this page, I felt they had robbed me of my last chance." ${ }^{6}$ Last chance for what? For Négritude!

Négritude, not necessarily in either its Senghorian nor in its Césairian form with both of which he had words, but Négritude itself, blackness with whatever values it

own, in Fumi Okiji, Jazz as Critique: Adorno and Black Expression Revisited (Stanford: Stanford University Press, 2018).

${ }^{2}$ Haun Saussy, Are We Comparing Yet?: On Standards, Justice, and Incomparability (Bielelfeld: Bielelfeld University Press, 2019), 95-97.

${ }^{3}$ For this reading, see also Robert Bernasconi, "The European Knows and Does Not Know: Fanon's Response to Sartre," in Frantz Fanon's “Black Skin, White Masks": New Interdisciplinary Essays, ed. Max Silverman (Manchester: Manchester University Press, 2012), 105: "Furthermore, although Sartre identified Negritude as 'an anti-racist racism,' a phrase that Fanon later employed for himself, ... by declaring that Negritude gives way to the idea of the proletariat, Sartre located Negritude as a stage in the dialectic and thereby robbed Fanon of his Negritude." Note that one does not have to claim that Fanon was not critical of Césaire's (or Senghor's) Négritude-nor is it possible-in order for him to be shocked and dismayed on discovering that Sartre intended his racial difference with all it entailed to be simply sublated. Bernasconi writes, and I concur, "Fanon is widely identified as a critic of the negritude movement. This impression is at best the result of an oversimplification of his rich and complex argument." See Robert Bernasconi, "The Assumption of Negritude: Aimé Césaire, Frantz Fanon, and the Vicious Circle of Racial Politics," Parallax 8.2 (2002): 76.

${ }^{4}$ Saussy, Are We Comparing Yet? 101.

${ }^{5}$ Jean-Paul Sartre, Black Orpheus, trans. S. W. Allen (Paris: Présence Africaine, 1976), 59-60.

${ }^{6}$ Frantz Fanon, Black Skin, White Masks, foreword by Kwame Anthony Appiah, trans. Richard Philcox ([1952]; reprint New York: Grove, 2008), 112. 
comprised for Fanon. ${ }^{7}$ I judge that Saussy's reading is compelling, if certainly not the only possible one. ${ }^{8}$ As Fanon wrote, once more, in the book, "What is certain is that, at the very moment when I was trying to grasp my own being, Sartre, who remained The Other, gave me a name and thus shattered my last illusion." "The last illusion, last chance" is for a Césairian universalism that does not demand sameness, an Aufhebung that does not realize human society without race. ${ }^{9}$ I want to

\footnotetext{
${ }^{7}$ It is, of course, well known by now that in his later writings, "we see him firing red-hot broadsides into Negritude, and condemning it in the most radical terms throughout his work." See Albert Memmi, "The Impossible Life of Frantz Fanon," trans. Thomas Cassirer and G. Michael Twomey, Massachusetts Review 14.1 (Winter 1973): 17. Memmi gives an astute account of Fanon's turn to "universalism" toward the end of his life (Memmi, "The Impossible Life of Frantz Fanon," 29).

${ }^{8}$ Compare for quite a different take on this passage in Fanon, Reiland Rabaka, Forms of Fanonism: Frantz Fanon's Critical Theory and the Dialectics of Decolonization (Lanham, MD: Lexington Books, 2010), 71-72. I am, as I've said in the text, quite close in my reading of Fanon with Saussy's. It was indeed Saussy's work that reminded me of this passage in Fanon and sent me to reread the work after some thirty years: "When I read this page," said Fanon in 1952, "I sensed that my last chance was being taken away from me." A little sacrifice is demanded for the sake of the world proletariat-very little, in the larger order of things-just an erasure of your markedness, which as we know is in the nature of a supplement to that regular order of things ... But there is a "larger" or "regular" order of things only from a certain perspective, and Fanon will not go along with it. "I am not a possibility of something else, I am fully what I am. It is not incumbent on me to pursue the universal." See Saussy, Are We Comparing Yet? 101. See too Daniel Boyarin and Jonathan Boyarin, "Diaspora: Generation and the Ground of Jewish Identity," Critical Inquiry 19.4 (Summer 1993): 699-701, on Lyotard especially and on Lyotard's sublation of the Jews into the jews. I am not asserting here that Fanon was a proponent of Senghor's or Césaire's version of Négritude. The good faith of my approach to Césaire and Fanon in a polemic essentially about Jews has been called into question. Just for the record, it seems to me that it needs no defense or justification given the analogies (not quite homologies) that those two authors expressed passionately between Jews and Blacks, most movingly perhaps in Césaire's powerful assertation: "When I switch on my radio and hear that black men are being lynched in America, I say that they have lied to us: Hitler isn't dead. When I switch on my radio and hear that Jews are being insulted, persecuted, and massacred, I say that they have lied to us: Hitler isn't dead" (cited from memory in Fanon, Black Skin, White Masks, 70). See too for a quite different reading of Fanon's encounter with Sartre, Memmi, "The Impossible Life of Frantz Fanon," 18-19. For a quite different take on Fanon's Jews, see Bryan Cheyette, "Frantz Fanon and the Black-Jewish Imaginary," in Frantz Fanon's "Black Skin, White Masks": New Interdisciplinary Essays, ed. Max Silverman (Manchester: Manchester University Press, 2012), chap. 4. See also his comments in the forum accompanying this article.

${ }^{9}$ I thus reject Memmi's reading of Fanon as having abandoned his negritude:
}

He could have concluded by identifying with his misfortune and trying to confront it directly in order to transform it. Or he could have evaded it, an alternative reaction common to many oppressed; and in the end that is what he chose to do. This choice had decisive consequences for his subsequent work. The first of these was his totally negative and very questionable conception of Negritude. After all, Negritude implies more than the mere consciousness of misfortune and of belonging to a vanquished group. It is also recognition and affirmation of self; it is protest, reconstruction of a culture, at least of its potential, positive adherence to a group, and the decision to contribute to a collective future. The disdainful abandonment of Blackness (or Jewishness, or Arabness) in the name of universalism and universal man rests on a misconception. This is not the place to go into a thorough critique. It should, however, be pointed out that such an outlook of false universalism and abstract humanism is based on neglecting all specific identity and all intervening social particularities, though it is hard to see why these are necessarily contemptible nor how they could be dispensed 
nuance this claim in a somewhat uncommon fashion. In the second-century gospel of Thomas, saying 114, we notoriously read: "Simon Peter said to them: Let Mariham go out from among us, for women are not worthy of the life. Jesus said: Look, I will lead her that I may make her male, in order that she too may become a living spirit resembling you males. For every woman who makes herself male will enter into the kingdom of heaven." I suspect that Fanon's affect at his encounter with Sartre must have been something like Mary's at that moment. ${ }^{10}$

A closer reading of Black Skin, White Masks is now in order. In his foreword to the English translation of Black Skin, White Masks, Kwame Anthony Appiah has referred appositely to Fanon's "dialogue with Négritude, then the dominant system of thought among black francophone intellectuals." On the one hand, as Appiah points out, Fanon seriously critiqued the ascription of a particular sort of mind to Black folks, arguing that this is precisely a European (and racist) fantasy. At the same time, however, Appiah asserts that "he conceded that Négritude could play an important role in freeing the native intellectual of dependence on metropolitan culture," 11 and clearly, I would add, not as a negative moment in a dialectic, an antithesis. Otherwise, how can we explain his sickened response to Sartre? At any rate, it is crucial not to miss Fanon's, "the black man who strives to whiten his race is as wretched as the one who preaches hatred of the white man," ${ }^{12}$ which Robert Bernasconi glosses, "To renounce his race is not an option for Fanon." ${ }^{13}$ Fanon, like Césaire, both Marxists, seeks justice for all the wretched of the earth, but not at the expense of his Négritude. Having learned much from Fanon as well as from Césaire, that is, as a so-called White theorist having been taught by Black thinkers, I want to go into some more detail here on Négritude and especially Fanon's response to it and also to think about Judaitude (my shameless coinage) and race.

Fanon's struggles with Négritude are well known. Is it indeed with regard to Négritude that he marks the following ambivalence?:

The educated black man, slave of the myth of the spontaneous and cosmic Negro, feels at some point in time that his race no longer understands him. Or that he no longer understands his race.

He is only too pleased about this, and by developing further this difference, this incomprehension and discord, he discovers the meaning of his true humanity. Less commonly he wants to feel a part of his people. And with feverish lips and frenzied heart he plunges into the great black hole.

with. Universal man and universal culture are after all made up of particular men and particular cultures (Memmi, "The Impossible Life of Frantz Fanon," 34).

I agree with Memmi's own critique here of "cosmopolitanism" but think he has missed the conflict, the ambivalence in Fanon himself for which I try here to make a case. See too Bernasconi, "The Assumption of Negritude," 73, for Fanon's rejection of an abstract universalism.

${ }^{10}$ The prompt was Fumi Okiji's; the strategy for responding, all mine, for good or for ill. I learned this strategy of explaining a narrative by putting another narrative next to it from the Babylonian Talmud and from "Darmok and Jalad at Tanagra" (a Star Trek episode with a PhD of its own).

${ }^{11}$ Fanon, Black Skin, White Masks, viii.

${ }^{12}$ Fanon, Black Skin, White Masks, xii.

${ }^{13}$ Bernasconi, "The European Knows and Does Not Know," 108. 
We shall see that this wonderfully generous attitude rejects the present and future in the name of a mystical past. ${ }^{14}$

This is a very prickly and difficult passage indeed. For the nonce, let me only note ironic possibilities of reading each of the alternatives bespeaking an area of difficulty, even a dilemma or aporia (a crossroads in which every choice to go forward leads to disaster) ${ }_{1}^{15}$ for Fanon. I want to propose as a working hypothesis that his dilemma is not entirely unrelated to that of the sage Hillel, who said: "If I am not for myself, who will be for me, and if I am only for myself, what good am I?" And then followed it up with a call to action, namely, "And if not now, when?!" [Mishna Avot 1:14]. (note Fanon's expression of "the black man's dimension of being-for-others.") ${ }^{16}$ If one wishes to erase one's "race," it is, as we've seen previously, as disgusting to Fanon as preaching hatred of the White man, and here, the desire for and pleasure in incomprehension of his race, in which "he discovers the meaning of his true humanity" (which I take as irony), is nearly as troubling as "the great black hole." Fanon's expressed disgust at the alleged development of drugs to whiten the skin also speaks to this reading as making sense of Fanon's nausea.

In the stunning fifth chapter of Black Skin, White Masks, Fanon explicitly works out a genealogy of his self and his progress to and through Négritude. Less surprising to me now than it would have been once, this Bildungsroman is deeply involved with Judaïté as well. He initiates this part of his account, just following the famous primal scene of the child and on the train by declaring. "It's in the name of tradition that the anti-Semites base their "point of view." 17 Fanon goes on to remark that it might seem strange to equate anti-Semitism with negrophobia, but then recounts when he had been taught that equation, namely by his philosophy teacher in the Antilles who asserted clearly: "When you hear someone insulting the Jews, pay attention; he is talking about you." And Fanon assents,

\footnotetext{
${ }^{14}$ Fanon, Black Skin, White Masks, xviii. This "black hole" remains a haunting presence throughout the book: "After having driven himself to the limits of self-destruction, the black man, meticulously or impetuously, will jump into the 'black hole' from which will gush forth 'the great black scream with such force that it will shake the foundations of the world"' Fanon, Black Skin, White Masks, 175. Bernasconi has written, "However, the fact that Fanon dismisses that conception of negritude that privileged the past should not lead one to assume that he rejected all conceptions of negritude. It was clear to Fanon that the negritude movement was not homogeneous and that Senghor and Césaire represented different conceptions of its potential. And the fact that Fanon uses the phrase 'Tower of the Past' to characterize what he rejects suggests that he might be exempting Césaire, who had written, as Fanon repeatedly reminds us, 'My negritude is neither a tower nor a cathedral"' (Bernasconi, "The Assumption of Negritude," 73).

15 "In philosophy, an aporia is a philosophical puzzle or a seemingly insoluble impasse in an inquiry, often arising as a result of equally plausible yet inconsistent premises (i.e., a paradox). It can also denote the state of being perplexed, or at a loss, at such a puzzle or impasse. The notion of an aporia is principally found in Greek philosophy, but it also plays a role in post-structuralist philosophy, as in the writings of Jacques Derrida and Luce Irigaray, and it has also served as an instrument of investigation in analytic philosophy." Wikipedia ad loc. I use the term in a closely related sense, drawing on its etymology of im and passe.

${ }^{16}$ Fanon, Black Skin, White Masks, 1.

${ }^{17}$ Fanon, Black Skin, White Masks, 101.
} 
"Since then, I have understood that what he meant quite simply was that the anti-Semite is inevitably a negrophobe." Strikingly, and without further elaboration at this point, it is precisely here in his tale of self that Fanon "finally made up my mind to shout my blackness." In the next two pages or so, with enrapturing quotations from Senghor and Césaire, Fanon evokes (ruefully?, somewhat ironically?) the excitement of that youthful shout of Blackness from his throat as well as the depths of its dangers, "the great black hole" of which he has warned. But this moment concludes:

Yes, we niggers are backward, naive, and free. For us the body is not in opposition to what you call the soul. We are in the world. And long live the bond between Man and the Earth! Moreover, our writers have helped me to convince you that your white civilization lacks a wealth of subtleness and sensitivity. ${ }^{18}$

With this, he continues citing Senghor on "Negro emotion." Fanon evokes brilliantly, thrillingly, the excitement of the young Black man-himself-who discovered Senghor and his version of Négritude. But then: "I was soon to become disillusioned." 19 All of that beautiful emotion and rhythm, all of that Négritude was ascribed by Whites to the earlier stages of the human race that they had already superseded (and I use that term on my own advice). The next stage of Fanon's ascribed self-genealogy involves the African pride of another form of Négritude, the glorying in the great Black civilizations of the past. ${ }^{20}$ But that also was contemned by the Whites:

I couldn't hope to win. I tested my heredity. I did a complete checkup of my sickness. I wanted to be typically black-that was out of the question. I wanted to be white-that was a joke. And when I tried to claim my negritude intellectually as a concept, they snatched it away from me. ${ }^{21}$

And with this, we arrive at Sartre, who has robbed Fanon of his negritude, even more than of his Négritude: "We had appealed to a friend of the colored peoples, and this friend had found nothing better to do than demonstrate the relativity of their action." By "relativity," of course, Fanon means precisely that negative, merely antithetical, cancellable (sublatable) moment in the dialectic:22 "While I, in a paroxysm of experience and rage, was proclaiming this [Senghorian Négritude], he [Sartre] reminded me that my negritude was nothing but a weak stage. Truthfully, I'm telling you, I sensed my shoulder slipping from this world, and my feet no longer felt the caress of the ground. Without a black past, without a black

\footnotetext{
${ }^{18}$ Fanon, Black Skin, White Masks, 106.

${ }^{19}$ Fanon, Black Skin, White Masks, 108.

${ }^{20}$ Fanon, Black Skin, White Masks, 109-10, citing now Césaire.

${ }^{21}$ Fanon, Black Skin, White Masks, 111.

${ }^{22}$ Sartre, here, the very fount of existentialism, robs Fanon of his existence by ascribing an essence to the "Negro" that precedes their existence! (Fanon, Black Skin, White Masks, 114-15.
} 
future, it was impossible for me to live my blackness." 23 And yet, "with all my being, I refuse to accept this amputation." ${ }^{24}$ Rabaka has glossed this passage powerfully: "Fanon found Sartre's Hegelization of Negritude not only paternalist, but also indicative of his infantilization of blacks, the 'childhood of the world.' Fanon knew all too well that Negritude had its limitations, but he also knew that existential phenomenology and Marxism had their limitations-something most existentialists, phenomenologists, and Marxists seemed extremely reluctant to admit." 25 This knowledge of limitations without rejection is, I think, one key to Fanon's evident ambivalence. As Robert Bernasconi has perspicaciously written:

He does not present an external critique of negritude, but an attempt to engage with it from the inside. However, he does not seem to offer any kind of resolution of the difficulties there. At one point Fanon announces that "every hand I played was a losing hand." The final sentence of the chapter reads: "Irresponsible, straddling Nothingness and Infinity, I began to weep." He repeatedly describes his experience as that of being in an infernal circle, and in the Introduction he declares the elimination of the vicious circle as the only guideline for his efforts. The question is whether Fanon finds a way out of the vicious circle and, if so, where Césaire stands in relation to that exit. ${ }^{26}$

Looking for a way out from the aporia, Fanon has traversed this inner journey of anguish beginning with Jews and indeed with his solidarity with Jews, the Jews being the ultimate sublatables (given to sublation) of Christendom. Jews are good for thinking with for Fanon ${ }^{27}$ and Fanon is good for thinking with for me, the Jew.

\section{Jews Are Good for Thinking With}

The attempt to think the aporias of Judaité alongside of Blackness, the endeavor to be taught by Black thinkers, is, thus, generated in part via Fanon's own observations on the nexus between Judaïté and Blackness. ${ }^{28}$ Lest it need pointing out-and

\footnotetext{
${ }^{23}$ Fanon, Black Skin, White Masks, 116-17.

${ }^{24}$ Fanon, Black Skin, White Masks, 119. Again Bernasconi, "The European Knows and Does Not Know," esp. 106, must be consulted for a deeper more complex reading that does not, I reckon, contradict or supplant what I offer here.

${ }^{25}$ Rabaka, Forms of Fanonism, 79.

${ }^{26}$ Bernasconi, "The Assumption of Negritude," 70, in a very important paper, has marked Fanon's ambivalence with respect to Césaire in contrast to his much less ambivalent reprobation of Senghor and Diop. I prefer "ambivalence” to Bernasconi's “ambiguity," although by page 75, Bernasconi is also talking of ambivalence.

${ }^{27}$ When speaking of the "Black man," Fanon has no difficulty at all in referring to the experience of Jews-not that he identifies them, nor do I-but the power of extimacy is palpable.

28 "All they ask of the black man is to be a good nigger; the rest will follow on its own. Making him speak pidgin is tying him to an image, snaring him, imprisoning him as the eternal victim of his own essence, of a visible appearance for which he is not responsible. And, of course, just as the Jew who is lavish with his money is suspect, so the black man who quotes Montesquieu must be watched" (Fanon, Black Skin, White Masks, 18). Fanon clearly gets it too that the privilege afforded to Jews in our societies is a kind of trap as well: "The Arab is told: 'If you are poor it's because the Jew has cheated you
} 
it seems it does-my point is not to make an equivalence between Sho'ah and colonization or anti-Semitism and racism, neither historical nor moral, nor certainly to justify anyone's bad behavior (Zionism. An early anonymous reader suggested that the point of my paper was to suggest that because Blacks can have nationalism, Jews can too; I take this direct denial to reject such a reading) but to see what can be learned from putting Jewishness and Blackness in conversation with each other. On a more personal level-and the only evidence I offer here is my own experience-the descriptions that Fanon gives of the Black man desiring Whiteness have been matched in my life and in very similar ways to those that Fanon describes. Fanon cries out his own identification between colonial racism and racism against Jews:

Colonial racism is no different from other racisms.

Anti-Semitism cuts me to the quick; I get upset; a frightful rage makes me anemic; they are denying me the right to be a man. I cannot dissociate myself from the fate reserved for my brother. Every one of my acts commits me as a man. Every instance of my reticence, every instance of my cowardice, manifests the man. ${ }^{29}$

Fanon follows this clarion with invocations of Césaire's solidarity with Jews as well. ${ }^{30}$ Fanon, then, teaches us the dilemma, the dilemma between desire for decolonized identity, as African, as Jew, and the disasters that ensue when one falls into the black hole of an exclusive identity politics (my language here is anachronistic, to be sure).

The most remarkable passage in Black Skin, White Masks regarding the ligature between Jews and Blacks is the following. I quote it here in, too, so that its power and complexity can be encountered, and then I'll discuss it at some length, at the length it deserves, to the best of my ability:

The Jewishness of the Jew, however, can go unnoticed. He is not integrally what he is. We can but hope and wait. His acts and behavior are the determining factor. He is a white man, and apart from some debatable features, he can pass undetected. He belongs to the race that has never practiced cannibalism. What a strange idea, to eat one's father! Serves them right; they shouldn't be black. Of course the Jews have been tormentedwhat am I saying? They have been hunted, exterminated, and cremated, but these are just minor episodes in the family history. The Jew is not liked as soon as he has been detected. But with me things take on a new face. I'm not given a second chance. I am overdetermined from the outside. I am a slave not to the "idea" that others have of me, but to my appearance. ${ }^{31}$

and robbed you of everything.' The Jew is told: 'You're not of the same caliber as the Arab because in fact you are white and you have Bergson and Einstein.' The black man is told: You are the finest soldiers in the French empire" (Fanon, Black Skin, White Masks, 83).

${ }^{29}$ Fanon, Black Skin, White Masks, 69.

${ }^{30}$ Jonathan Boyarin and I are preparing now a study of Césaire and the Jewish Question.

${ }^{31}$ Fanon, Black Skin, White Masks, 95. 
Fanon's ambivalence with regard to the Jew here is tangible. On the one hand, he produces here, as in several places throughout the book, expressions of the most categorical solidarity and comparability with Jews, but in this famous passage that solidarity is tinged with something else, something that Fanon himself detects and is shocked at: "Of course the Jews have been tormented-what am I saying? They have been hunted, exterminated, and cremated, but these are just minor episodes in the family history." Jews are firmly identified here with "Whites" because of their alleged possibility of "passing," as it were. "Apart from a few debatable features" (Does Fanon here mean "Jewish noses?" Fanon apparently knew nothing of Jews of color but that is another problem.). The text itself is dismayed by this sudden disavowal. I want to propose that here, as in many places, Fanon is marking through the Jew his own ambivalence between asserting his Black identity and wishing to escape it, envious for the moment, it seems, of the Jew who allegedly can escape their identity, apart from those debatable features. As support for this reading, let me quote again: "the black man who strives to whiten his race is ...wretched" and it would be hard to ascribe this wretchedness to a mere inability to perform this whitening.

Fanon also uses this difference between the allegedly White Jew and the Black man to generate, construct, and justify treating the Black man as a single category as opposed to the "Hova, the Moor, Tuareg, Fula, or Bantu": "The universal situation of the black man is ambiguous, but this is resolved in his physical existence. This in a way puts him beside the Jew. In order to counter the alleged obstacles above, we shall resort to the obvious fact that wherever he goes, a black man remains a black man." 32 The Jew has no such features that mark them always and everywhere and, therefore, what precisely? They can choose to disappear to put on French, British, or German masks.

This "whiteness" or invisibility of the Jew is a trap as well as a refuge. Perhaps I sat on a train at a time in my life when I was not so detectable as a Jew and sitting across from me in the subway car was a Hassid from Brooklyn. "Look Mom, look, a Jew! dirty. Ikh.” If I am silent at that moment, I have alienated myself from myself; if I speak, then I have been "detected." The epistemology of the closet. Despite Fanon's envy of the Jew's alleged possibility of disappearance-notoriously it didn't work too well among the Nazis-he too understands well the psychic cost of deracination.

\section{What to Do in an Aporia}

"If we are for ourselves, what good are we?" We Jews, ourselves, have seen the calamities wrought by not pursuing any solidarity beyond the racial or national (especially in the Israeli state), producing the dilemma or even paradox (alluded to previously): "If I am not for myself, who will be for me, but if I am for myself, what good am I?" (Mishna Avot 1:14), to which, however, the sage added, "And if

\footnotetext{
${ }^{32}$ Fanon, Black Skin, White Masks, 150. I quite disagree with Bernasconi's reading of this passage (Bernasconi, "The Assumption of Negritude," 76) because it totally elides (literally under eliptical dots) the contrast with Jews in which the statement functions.
} 
not now, when?" Something must be done. One cannot wallow. I offer the dual loyalties and doubled culture of the diaspora nation. The diaspora nation (as a model) suggests another way, leading to (never perfectly, of course) ardent trans-territorial collective solidarity-the nonsovereign nation-and ardent solidarity as well with proximate others-the local oppressed class/proletariat, racial group, BLM, not an abstraction at all-at the same time.

I am striving here to solve problems of my own/our own in a context that implicates not only us, the Jews, but interacts with and perhaps has implications for the imagination of different futures for Fanon's "wretched of the earth." The Jews are perhaps not quite the wretched that they were once upon a time (and not so long ago), but undertows of anti-Semitism still runs strong and deep in the social waters of Europe and America. Not threatened now, almost anywhere, with the soul-crushing pervasive and literally deadly racism that down-presses Blacks, we are indeed commanded through ideological state and ideological nonstate apparatuses to leave behind our Judaïtude, our Jewissance, and become indistinguishable in the society except in the most trivial ways. "If we are not for ourselves, who will be for us?" So much of Fanon speaks to me directly, owing to his eloquent and precise analysis of these forces of deracination. Not only that, but so much of Fanon speaks to me directly owing to the ambivalence of his own discourse between a commitment to African, even Black, language and cultural forms and a powerful commitment to some version of cosmopolitanism at the very same time. Fanon's struggles with Négritude are not the same-of courseas my struggles around Judaiité, but they are not, as Fanon realized, incomparable to the point, I trust, where we can learn, at least a solidarity as poignant as Fanon's own. I hope to make some theoretical intervention into that dilemma. I propose an image, not quite a chimera even now, but a real actionable possibility of the "diaspora nation," the nation denuded of sovereignty and given its full cultural/linguistic/political weight absent the mononational state. It is, after all, only recently that the concepts of nation and state have begun to collapse into each other.

\section{The Deracinated of the Earth}

In his close concept-history, word-history, of nación in Spanish usage, E. J. Hobsbawm has shown that it is only in 1884 that the association of "nation" with "a State or political body" appears in the dictionary of the Spanish Academy. ${ }^{33}$ Even then, it doesn't settle there because in the final edition of that textual monument from 1925, a nation is defined as "the collectivity of persons who have the same ethnic origin and, in general, speak the same language and possess a common tradition." ${ }^{34}$ In other words, in that

\footnotetext{
${ }^{33}$ Haun Saussy reminds me: "This older use of "nation" can also be found in, e.g., the Collège des Quatre Nations (a subpart of the old Sorbonne formerly housed in the buildings now occupied by the French Academy)."

${ }^{34}$ E. J. Hobsbawm, Nations and Nationalism Since 1780: Programme, Myth, Reality (Cambridge: Cambridge University Press, 1992), 15-16.
} 
linguistic/cultural world, the association of nations with states, as an integral part of their very being nations, was late and contested. ${ }^{35}$ Hobsbawm makes the same point with respect to other languages including German and Dutch, summing up that:

The problem of the relation of even such an extended but indigenous "nation" to the state remained puzzling, for it seemed evident that in ethnic, linguistic or any other terms, most states of any size were not homogeneous, and could therefore not simply be equated with nations. The Dutch dictionary specifically singles out as a peculiarity of the French and English that they use the word "nation" to mean the people belonging to a state even when not speaking the same language... . From this it follows that it can have no territorial meaning, since members of different nations (divided by "differences in ways of life-Lebensarten-and customs") can live together in the same province, even quite a small one. ${ }^{36}$

The upshot of this is that "nation" has a much longer history (within modernity itself) in the nonterritorial, nonstate sense than we imagine. I couldn't imagine a more trenchant statement of the state of the "nation" than Hobsbawm's: "Whatever the 'proper and original' or any other meaning of 'nation,' the term is clearly still quite different from its modern meaning. We may, thus, without entering further into the matter, accept that in its modern and basically political sense the concept nation is historically very young." ${ }^{37}$ I offer the proposition that if the evident toxicity of both nation and nationalism is a product of the inexorable association with sovereignty, the nation-state, then imagining a form of national existence that is explicitly counter-sovereign-"unstated we could say"-might be a way to save the nation as an aggregation of folks with a common Lebensart and stories about themselves and each other. ${ }^{38}$ This is my schema to save the nation of the Jews.

\footnotetext{
${ }^{35}$ Ato Quayson has pointed to the irony of the fact that in the same year that nación becomes recognized as a sovereign political entity in the Spanish lexicon, the Berlin conference in which the Europeans and Americans met as nation-states themselves to divide Africa up into nation-states of its own. At least some of the problems of modern Africa seem to me (and I am no Africanist) to stem from such artificial divisions, viz Rwanda.

${ }^{36}$ Hobsbawm, Nations and Nationalism Since 1780, 17 emphasis added.

${ }^{37}$ Hobsbawm, Nations and Nationalism Since 1780, 17-18. Hobsbawm cites as well the Oxford English Dictionary, which remarks explicitly that the notion of "political unity and independence" for the nation is a recent one-in 1908 !

${ }^{38}$ The significance of this cannot be more strongly articulated than Aamir Mufti's formulation: "The inherent failure of the modern nation-state system, the recurring crises it engenders about 'national' peoples and 'minorities,' is condensed in concentrated form, and revealed with unrelenting clarity, in the conflict over Palestine and the nature of the Jews and the Palestinians as distinct peoples" (Aamir R. Mufti, Enlightenment in the Colony: The Jewish Question and the Crisis of Postcolonial Culture [Princeton, NJ: Princeton University Press, 2007], 38).
} 


\section{Partha Chatterjee and "Spiritual Nationalism"}

My insistence on the word nation puzzles-and even repels-many of my associates, colleagues, and friends alike and very likely many of you, my readers, as well. As Partha Chatterjee has characterized the current discursive situation of "nationalism," it was:

by the 1970s, the reason why people in the Third World killed each othersometimes in wars between regular armies, sometimes, more distressingly, in cruel and often protracted civil wars, and increasingly, it seemed, by technologically sophisticated and virtually unstoppable acts of terrorism. The leaders of the African struggles against colonialism and racism had spoiled their records by becoming heads of corrupt, fractious, and often brutal regimes; Gandhi had been appropriated by such marginal cults as pacifism and vegetarianism; and even Ho Chi Minh, in his moment of glory was caught in the unyielding polarities of the Cold War. Nothing, it would seem, was left in the legacy of nationalism to make people in the Western world feel good about it. ${ }^{39}$

No wonder my friends and relations are, almost to a person, appalled by my vaunting of a nationalism, any nationalism. In this manifesto, I hope to save the nation, namely, to demonstrate the continued vitality (creative energies) and utility (force for good) of this narrative in thinking about human collective lives.

Chatterjee moves us forward in understanding the shifts in the concept "nation" but at the same time takes what I consider a critical wrong turn that needs correction if we are to move forward in imagining a new nation and a new nationalism-for the Jews and others. On the one hand, he makes us see that nationalism outside of the metropolis of Europe and the West is produced in opposition to and not conformity with the national society as developed in that metropolis. He writes evocatively that "the most powerful as well as the most creative results of the nationalist imagination in Asia and Africa are posited not on an identity but rather on a difference with the ... forms of the national society propagated by the modern West." He makes the crucial point (for me) that a large part of the misapprehension of nationalism is precisely in that it has been taken "to be a political movement [emphasis original]," or rather that it has taken nationalism's own claims to be a political movement too solemnly. ${ }^{40}$ On the other hand, here is where he makes his momentous mistake (in my humble opinion). I agree with him (and this is foundational for my claims here): Something has shifted over time in discourses of nationalism, Indian and Jewish, but, as I shall try to show in the particular case of Jewish nationalism at any rate, it is not "politics" that was introduced as Chaterjee describes it. Politics was always there necessarily. Rather statism, the insistence on sovereignty for the nation, is the novelty, and that is the worm that grew in the apple.

\footnotetext{
${ }^{39}$ Partha Chatterjee, The Nation and Its Fragments: Colonial and Postcolonial Histories, Princeton Studies in Culture/Power/History (Princeton, NJ: Princeton University Press, 1993), 3.

${ }^{40}$ Chatterjee, The Nation and Its Fragments, 5.
} 
Chatterjee distinguishes between two domains of practice in the anticolonial nation, which he names "material" and "spiritual," the former being the realm of the practical world, of politics, economy, statecraft, science, and technology, while the so-called spiritual bears the "'essential' marks of cultural identity." 41 Here is the parting of the ways between us. Chatterjee seems to be claiming that where nationalism has taken a wrong turn is in its overemphasizing the realm of the "political," while ignoring by and large the domain of the "spiritual," or cultural. What Chatterjee has failed to note is that by naming one "political" and one "spiritual," he is reinstating precisely the terms of the liberal European "arrangements" whereby something called religion is deemed to be untouchable by the state, while the state is (at least aspirationally), untouchable by "religion." 42 The description I am offering is commonplace by now, of course; the novelty is seeing how the historical shifts as rendered by Chatterjee do not escape but, rather, comply with the theory of the liberal secular state, leading right back to: be a universal (e.g., Englishman/German) in public and an Indian/ Hindu/Jew in your soul and your home.

We can begin to see both of these moments or aspects appearing at the same time and in the same paragraph of Chatterjee's writing:

The colonial state, in other words, is kept out of the "inner" domain of national culture; but it is not as though this so-called spiritual domain is left unchanged. In fact, here nationalism launches its most powerful, creative, and historically significant project: to fashion a "modern" national culture that is nevertheless not Western. If the nation is an imagined community, then this is where it is brought into being. In this, its true and essential domain, the nation is already sovereign, even when the state is in the hands of the colonial power. The dynamics of this historical project is completely missed in conventional histories in which the story of nationalism begins with the contest for political power. ${ }^{43}$

On the one hand, Chatterjee is absolutely correct. Nationalism is not to be identified with the fight for sovereignty, for the nation-state, the state that is only for members of the given nation, with others there on sufferance (more or less liberal sufferance). We miss nearly everything that is important and alive in the nation when we focus only on sovereignty. Nationalism is so much more than that fight; indeed, I hold that it is everything without that fight. Accordingly, Chatterjee points to the ways that the early nationalism conceived of "the 'spiritual' or 'inner' aspects of culture, such as language or religion or the elements of personal and family life" as the proper realm of the nation while the "outer" domain of the state, the "material domain of law, administration,

\footnotetext{
${ }^{41}$ Chatterjee, The Nation and Its Fragments, 6. For very useful reading of Chatterjee on this notion of "spiritual," see Mufti, Enlightenment in the Colony, 28.

${ }^{42}$ Chatterjee, of course, wrote before the worldwide reinventions of religio-ethno-nationalism as embodied in India in the rise to power of the Hindutva movement and its cognates in other places, such as the Evangelical Christian nature of Donald Trump's so-called "base."

${ }^{43}$ Chatterjee, The Nation and Its Fragments, 6.
} 
economy, and statecraft," had to be the same for the colonized nation as for the colonizers. The distinction is indeed crucial, but it simply cannot be mapped onto an "inner" or worse, "spiritual" dimension versus an "outer" or "material" one. Insofar as we (that is folks like Chatterjee or me) desire merely to give a historical account, it may certainly be correct to refer to the distinction in those terms, for it seems that thinkers did-then-and, indeed, we will see that distinction reproduced in Jewish discourse as the differentiation between the "political" and the "cultural" in Zionism itself. Insofar, however, as I am committed to a deliberative rhetoric here, a discourse of "What is to be done," there is no doubt in my mind that the terms of the necessary distinction need to be thoroughly revised, eschewing any oppositions between the material/political and the spiritual or cultural.

The transitions in Indian nationalism, as described by Chatterjee and those within Jewish nationalism to be detailed in the following, are, it seems to me, strikingly parallel. ${ }^{44}$ Thus, and I am reducing a complex and historically detailed argument to its bare bones here, while Indian nationalism focused initially on the apparently cultural aspects of the nation, languages, literatures, and practices and moved to a primarily political movement at a later stage ${ }^{45}$ a revisionist reading of Jewish nationalism carried out following will reveal comparable stages of development. The most important historical insight of recent historiography is that Jewish nationalism was not, by any means, identified with the state until quite late in its history and very near to the founding of that very state.

This parallel development is misdescribed as a shift from the spiritual to the materialist or political. The material life of the nation, the so-called political, is always present. The pivotal question is How can the members of different "nations" coexist in the same spaces in ways that are productive for all? How do we get to Césaire's "the coexistence of them all"? It will be seen immediatelyI hope-that putting the question in these terms and having rejected neoliberal cosmopolitanism and "ethnic cleansing" (hard or soft) from the realm of possibilities makes the distinction between political and cultural dimensions inoperable (and indeed anachronistic). I retain, then, the essence of Chatterjee's insight that there is something new that develops within Indian national thought and can be identified in Jewish nationalism as well, but I urge moving it from material/spiritual into another entirely material register. Only then can we see that it is the focus on monoethnic sovereignty that is the problem, not the

\footnotetext{
${ }^{44}$ Nor is this an accident-entirely. See the illuminating summary discussion of Mufti, Enlightenment in the Colony, 2-14, as well as the development of these ideas throughout his enlightening book, esp. 19-20, "on the crisis of authenticity" haunting Urdu culture, a discussion that I found curiously comforting in its similarity to the situation of the Jews).

${ }^{45}$ Chatterjee, The Nation and Its Fragments, 28-29 and passim. Especially in his detailed account of Bengali history writing, Chatterjee notes that it was only in the last quarter of the nineteenth century that "the identification in European historiography between the notions of country or people, sovereignty, and statehood is now lodged firmly in the mind of the English-educated Bengali" (Chatterjee, The Nation and Its Fragments, 95). For Jews educated rather in German historiographical traditions, this identification may have been slower to arrive.
} 
focus on the nation per se. Surprisingly-at least I was surprised-this passage takes place in the Jewish movement now most identified with the nation-state, Zionism, of course. Zionism is taken today as precisely the movement that successfully led to the Jewish State of Israel, that is as the very apotheosis of Jewish statist-nationalism. Seemingly at first paradoxically, a survey of some vitally important recent scholarship on the early history of Zionism-and especially two of its most canonical figures-helps make the case for the nation sans sovereignty, for what I call the no-state solution. ${ }^{46}$

\section{Theodor Herzl, Ahad Ha'am and the No-State Solution}

Following the cutting edge of recent historiography of Zionism, ${ }^{47}$ I'll discuss the startling but ultimately compelling proposition that the most canonical early thinkers of Zionism were not proponents of the nation-state but generated the idea of the stateless nation as the solution to the "Jewish Question"; diaspora as the answer to the Jewish Question, not itself the question. I will explore and define the concept of a diaspora nation; a nation that is itself the product of diasporas and whose very portion is diaspora.

Chatterjee remarks, "If the nation is an imagined community and if nations must also take the form of states, then our theoretical language must allow us to talk about community and state at the same time. I do not think our present theoretical language allows us to do this." ${ }^{18}$ It is the second of these premises that I contest. There is no reason to assume a priori that "nations must also take the form of states." Or rather, that is the question, the new Jewish Question, if you will.

What if nations do not have to take the form of states? What if the Jewish nation, I inquire, could thrive without a state, and by thrive I mean, of course, remain productively creative, vibrant, exciting, alive, while being equivalently alive to the needs and desires of others than Jews? Seemingly paradoxical but nonetheless also apparently the case, this seems to have been the dream of the earliest forms of the Jewish nationalist movement known as Zionism. As Dimitry Shumsky has demonstrated compellingly in his eye-opening recent book, neither Asher Ginzberg (Ahad Ha'am) nor even Theodor Herzl had even dreams of a Jewish state in the modern sense, opting instead, each in his separate fashion for a Jewish autonomous region with perhaps the vast majority of Jews in the world remaining outside that area, a sort of Gaeltacht if you will. ${ }^{49}$

It is fascinating to note that in the historiopoesis of Zionism, these two major thinkers have been assigned Chatterjee's roles of "nationalism as a political movement" and "spiritual nationalism," or "cultural nationalism," namely Theodor Herzl (1860-1904) and Asher Ginzberg (Ahad Ha'am; 1856-1920),

\footnotetext{
${ }^{46}$ Dmitry Shumsky, Beyond the Nation-State: The Zionist Political Imagination from Pinsker to Ben-Gurion (New Haven: Yale University Press, 2018).

${ }^{47}$ Noam Pianko, Zionism and the Roads Not Taken: Rawidowicz, Kaplan, Kohn, The Modern Jewish Experience (Bloomington: Indiana University Press, 2010); Shumsky, Beyond the Nation-State.

${ }^{48}$ Chatterjee, The Nation and Its Fragments, 11.

${ }^{49}$ Shumsky, Beyond the Nation-State.
} 
respectively. At least in one feature, this line-up is a perfect match. Herzl did not care at all for Jewish difference; in fact, he rejected it entirely, infamously writing in his diaries, "I am a German-speaking Jew from Hungary and can never be anything but a German. At present I am not recognized as a German. But that will come once we are over there." ${ }^{50}$ It is not insignificant that Herzl, himself an originally Hungarian Austrian, identifies himself explicitly as a German and not as an Austro-Hungarian or whatever the alternative to German might have been. This is, moreover, borne out entirely in Herzl's famous "utopian" novel, Oldnewland, depicting the fulfillment of the Zionist state in which that "Jewish State" is, in fact, a perfect copy of the German metropolis: at the opera they perform operas on biblical themes, and the Alexanderer Wunder-Rebbe (a highly powerful Polish Hassidic leader) has been translated into the bishop of Haifa. Not only does this fit perfectly with Chatterjee's image of the political nationalism of the excolony being forced to fit into the forms of Western European nationalism but also Homi Bhabha's descriptions of the ambivalent (to Bhabha too) mimic-men of colonialism. ${ }^{51}$ Herzl is, it seems according to that regnant interpretation, exemplary of the turn to nationalism as ethnic politics that Chatterjee identifies as the particular later form that nationalism takes.

Herzl's "Jewish State" is an autonomous part of a larger imperial or multinational democracy, but even so, once again, as Shumsky makes eminently clear, "Herzl intended his 'Jewish state' to make it easier for the Jews who remained in their home countries to either assimilate completely or else maintain an exclusively religious form of Jewish identity." ${ }^{2}$ The shocker here is that this research demonstrates Herzl to have been essentially an anti-nationalist Jew. The "Jewish State" (Judenstaat) itself envisioned by Herzl, moreover, was a substate autonomous region. Shumsky shows that the term Staat meant just that: "Most of the neighboring non-Jewish national movements of the Habsburg imperial space in Herzl's time used the term Staat with explicitly substatist intentions in their national political programs and position." ${ }^{33}$ Shumsky's revised and revisionist reading of the writings of those Jewish thinkers called Zionists-especially of Herzl, the putative godfather of the State of Israel-will meet with resistance, no doubt, but to this writer the documentation and interpretations offered by Shumsky provide more than full evidence for the novelty in the mid-twentieth century of the concept of a Jewish, fully sovereign nation-state in which all others who happen to be there are second-class citizens-at best. Let me just clarify that by "novelty," I don't mean that no one had ever thought of it before but that it is only then-at the Biltmore Conference of 1942-that it becomes practically synonymous with Jewish nationalism and especially with Zionism. In this respect, Herzl is no better, nor worse, than the other Zionist writers. What is unique, perhaps, is his total disregard for maintenance and continuing vitality

\footnotetext{
${ }^{50}$ See discussion of this thinking in Shumsky, Beyond the Nation-State, 57-59, for further elaboration and explanation of this seeming paradox in Herzl's thought.

${ }^{51}$ Homi K. Bhabha, "Of Mimicry and Men: The Ambivalence of Colonial Discourse," October 28 (1984): 125-33.

${ }^{52}$ Shumsky, Beyond the Nation-State, 45.

${ }^{53}$ Shumsky, Beyond the Nation-State, 79.
} 
and future for Jewish culture in all of its manifestations. In Herzl's Jews' state-“a non-Jewish state of Jews" (Shumsky's brilliant formulation)-Jewish culture is fully German in its nature, thus permitting the Jews back in Germany, simply to be Germans of the Mosaic persuasion-if that.

I think that this is hardly the place to go into detail on the reading of Herzl that supports these judgments as Shumsky's book is highly accessible to those interested, but suffice it to say once more that the primary difference-if not the only major difference-between Herzl's dream of a state of the Jews and that of other near-contemporary thinkers is that Herzl seemed to care very little indeed about the Jewish part of the state, seeking only to escape from harassment on the part of anti-Semites. Although not a politics of sovereignty that would only be read back into his writings after the establishment of the state, ${ }^{54}$ it is the case, it seems, that for Herzl, as for the latter-day nationalists in the postcolonial world discussed by Chatterjee, all that matters are governmental structures of one sort or another and not the cultural (Chatterjee's "spiritual") life of the nation, except insofar as it is mock German.

As emphasized correctly, however, by Shumsky, this does not negate a cultural dimension to Herzlian Zionism; this is not a culturally neutral stance. "Mock German" is precisely the cultural formation that Herzl dreams of for the Jews. ${ }^{55}$ Although Shumsky provides an elaborate cultural context for Herzl, arguing that German culture was indeed a species of Jewish culture for him and his social group, nonetheless Herzl's connection with any aspect of traditional (not a synonym for "religious") culture at all was tenuous at best. I have written on this point at greater length elsewhere. ${ }^{56}$ But see, meanwhile, Shumsky's report vis-à-vis Herzl that "the cultural homeland of the Zionist commonwealth is Europe and ... there are no signs of any disconnect from this homeland that in any way resembles a move from and 'exile' to a 'Zion." ${ }^{57}$ His Zionism is, thus, just as cultural as that of Ahad Ha'am; it's just not anything recognizable-to me-as "Jewish" culture. ${ }^{58}$ Once again, I find Fanon's analyses very helpful in thinking this through:

All colonized people-in other words, people in whom an inferiority complex has taken root, whose local cultural originality has been committed to the grave-position themselves in relation to the civilizing language: i.e., the metropolitan culture. The more the colonized has assimilated the cultural values of the metropolis, the more he will have escaped the bush. The more he rejects his blackness and the bush, the whiter he will become. ${ }^{59}$

\footnotetext{
${ }^{54}$ Shumsky, Beyond the Nation-State, 50, 89.

${ }^{55}$ Shumsky, Beyond the Nation-State, 59.

${ }^{56}$ Daniel Boyarin, "The Colonial Drag: Zionism, Gender, and Colonial Mimicry," in The PreOccupation of Postcolonial Studies, eds. Kalpana Seshadri-Crooks and Fawzia Afzal-Kahn (Durham, NC: Duke University Press, 2000), 234-65.

${ }^{57}$ Shumsky, Beyond the Nation-State, 84.

${ }^{58}$ Pace an anonymous sniper, this claim has nothing to do with me being an "orthodox Jew," any more than Fanon is writing from the point of view of an African religionist.

${ }^{59}$ Fanon, Black Skin, White Masks, 2-3.
} 
In accordance with Fanon's own moves in this very context of observing this very configuration of deracination in different cultural/social locations, all we need to do is plug some new values into the equation and Herzl emerges clearly; the local cultural originality is in Hebrew and Yiddish (in Europe); the metropolitan language/culture is German, as are its cultural values. ${ }^{60}$ The bush is the ghetto, and "the more he rejects his Jewishness and the ghetto, the 'whiter' [more Gentile] he will become." "Whiten the race, save the race, but not along the lines you might think; do not safeguard "the originality of that part of the world in which they grew up,' but ensure its whiteness." Ensure the German-ness of the Jews. The quotation from Herzl bears repeating: "I am a German-speaking Jew from Hungary and can never be anything but a German. At present I am not recognized as a German. But that will come once we are over there." ${ }^{61}$

Mitigating this point somewhat and providing some support for Shumsky's view is the situation of Jews in North Africa, for instance. Some twenty years ago, an Egyptian professor in her sixties was quite shocked to find out that we don't speak French fluently: "But you are Jews, aren't you?" she asked incredulously. In other words, speaking French was marked for this person as a typically Jewish cultural performance, supporting via parallel Shumsky's interpretation of Herzl's claim for German. Shumsky fascinatingly shows that bilingualism, that is the language of a specific nation alongside of German, was considered an integral part of the national culture by nationalist thinkers. Among the examples offered by him are Czech and Slovenian. In some cases, the national language was afforded primacy with German bearing a secondary role; in some cases the opposite. Shumsky compares Herzl's attitude to German culture for the Jews to the second option, with Yiddish as the secondary language. ${ }^{62}$

So far, quite illuminating. Herzl's notion of a German-speaking, Germanidentified polity in Palestine is not as odd as one had thought. Where Shumsky's argument on this point breaks down quite completely in my opinion is when he goes on to compare an important Sefardic Zionist thinker of the same time as Herzl himself, namely the Tunisian historian and journalist Nissim Malul (18921959). In Shumsky's view Malul espoused "cultural-national approaches clearly paralleled [to those of] Herzl and Nordau." 63 They are parallel, according to Shumsky, because Malul manifested deep attachment to Arabic and Arabic culture as well as passionate concern for Jewish national culture in Hebrew. The positions, however, could not be further apart. Herzl demands that the primary national cultural language be the language of a land and an empire far away (with appropriate refresher trips every couple of years), a language that would separate the Jews in Palestine from their non-Jewish neighbors as well as from the entire circumambient world, while Malul argues for development of a bilingual culture in which Jews participated in the local language world of

\footnotetext{
${ }^{60}$ It is striking how Fanon describes the relation of the Black bourgeoisie in Martinique to Creole. The vicious response of such as Herzl to Yiddish is so close as to be nearly palpable.

${ }^{61}$ See discussion of this thinking in Shumsky, Beyond the Nation-State, 57-59, for further elaboration and explanation of this seeming paradox in Herzl's thought.

${ }^{62}$ Shumsky, Beyond the Nation-State, 74.

${ }^{63}$ Shumsky, Beyond the Nation-State, 75.
} 
Palestine and the surrounding Arabic people as well as developing their Hebrew, national culture. Malul would be similar to Herzl had he proposed that the Jews of Palestine speak French and Hebrew-but he didn't. In any case, a further development of this argument would require a much more capacious account of Sefardic and Mizrachi thinking on the Jewish nation than I am competent to provide.

The other vitally important and paradigmatic Zionist thinker, Ahad Ha'am (Asher Ginzberg [1885-1827]), in contrast, focuses acutely on Jewish cultural difference and how it might be continued, vital and significant, into the future within a political framework nearly identical to that of Herzl, substate autonomy in Palestine and elsewhere. He is, therefore, in Zionist historiography dubbed the founder of so-called "cultural Zionism." The purpose of this autonomy, however, is entirely other to Herzl's. If for Herzl the stated purpose of getting away from the anti-Semites in Europe was to become culturally proper Germans, for Ahad Ha'am it was to have space within which to produce a Hebrew, Jewish cultural modernity, deeply rooted in the ancient forms, languages, and practices of the past. This was not, I hasten to add, an isolationist or chauvinist one (not at all a "new Greece" in Herzl's infelicitous and contemptuous formulation). This autonomous region in Palestine was then meant to be the epicenter of a constant renewal of a Jewish culture throughout the world wherever Jews lived as well.

Indeed, as Shumsky demonstrates compellingly, Ahad Ha'am's political thought has been consistently distorted by readings generated within the ideological paradigm of the Israeli nation-state that identifies the state as the only possible political telos for a Jewish nationalism that might claim the name Zionism. As he shows in his rich chapter on the political thought of Ahad Ha'am, this thinker's thought was as political as Herzl's-as he had previously shown that Herzl's thought was as "cultural" as Ahad Ha'am's. On the political level, both imagined shared substate cultural autonomies in the territory of Palestine. It is on the cultural level that they, I repeat, diverged. Herzl's commitment to a shared Central European-German-culture for both Jews and Muslims in Palestine, it would seem, put less pressure on the idea of binational existence, while Ahad Ha'am's dream of a vibrant national culture for the Jews, worldwide but with Palestine as its epicenter, required in fact considerable more thought on the political level, including Ahad Ha'am's explicit demand that rights must be equal for the two nations sharing the territory and the sovereignty. Shumsky establishes how consistent Ahad Ha'am's vision was of the contemporary situation of many peoples in their time and place: "In this reality, different nations sought to preserve and reinforce their particular identities while simultaneously maintaining economic relationships and day-to-day cultural loyalties within spaces that were shaped by a slew of different group identities." ${ }^{44}$ In other words, Ahad Ha'am's vision of a Jewish cultural center that empowers and enlivens the cultural lives of Jews in many other places "had clear parallels in the lives of neighboring peoples in the imperial world. Indeed, it appears that the spiritual center idea

${ }^{64}$ Shumsky, Beyond the Nation-State, 91-92. 
was not at all disconnected from the concrete reality of Ahad Ha'am's time."65 Ahad Ha'am himself gave the brilliant comparison with Warsaw, which was certainly the cultural epicenter of Polishness in music, in art, in thinking, in language and literature, while hardly being the economic or sovereign center of Polish life in the lands in which Poles lived, for example, Galicia, until 1918 a province of Austria. What characterizes Ahad Ha'am's thought, then is the notion of full cultural life for the nation in contact with others and in spaces of shared sovereignty with other nations equally devoted to the fullness of their cultural, national futures. And this can be understood as the major contribution of Ahad Ha'am to an imagined Jewish future now. For Ahad Ha'am, erasing Jewish (Hebrew) culture was hardly a contribution to openness and pluralism; indeed Herzl's slogan, "regardless of religion and nationality," "has no other meaning than to deny Ahad Ha'am's right to cultural difference." ${ }^{66}$ The bottom line is that, as Shumsky makes clear as light, the distinction of so-called "political Zionism" from so-called "cultural Zionism" is a false and ideological binary from post-state historiography (I don't say "Israeli” because many Jewish historians who live outside of Israel adopted it as well.)

I wish once more to emphasize, as I conclude this section of my presentation here, that I am not promoting a gentler, kinder version of Zionism. Any version of that program-whether statist or substate autonomy-involves and always involved grave appropriation of the territories of other peoples who already lived in Palestine and had done so for well over a millennium. Let us not forget that for all the appeal that Ahad Ha'am's sense of the value of cultural difference holds (at least for me), it involved as well the notion that "the constant renewal of Jewish life in the diaspora would be impossible without establishing a national center in Palestine." ${ }^{67}$ No one was asking the Palestinians, the people who were already there. I am neither promoting nor apologizing for any form of Zionism. These visions of substate autonomies do point the way, however, to deterritorialized nationalisms and especially to nationalisms that are not founded on ethnic sovereignties, on national self-determination in the sense to which we have become accustomed. If we abandon-as both historicizable and deconstructible-the very opposition between the political and cultural, we can see that the crux of the matter is the shift from nationalisms without mononational sovereignty to nationalisms that insist on the plot of land that belongs to one nation and in which all members of that nation would normatively and ideally live. In moving to a more complete characterization of the nationalism that I have in mind, a move out of the Zionist thought world is thus imperative, or do I, perhaps, mean mandatory. The twoness or doubledness can be now productively shifted to a twoness on the very material plane (the only plane that I recognize) of the life of the nation within itself, wherever it is, and the life of the nation in contact, even intimate contact, with other nations sharing the same space(s). The notion of the culture nation, the Kulturvolk, provides promising food for thought

\footnotetext{
${ }^{65}$ Shumsky, Beyond the Nation-State, 100.

${ }^{66}$ Shumsky, Beyond the Nation-State, 105.

${ }^{67}$ Shumsky, Beyond the Nation-State, 113.
} 
but that shall have to remain for another day (עוד חזון למועד). without saying that the two domains, one inward-facing to the life of the nation and one outward-facing to the shared life of the state, or perhaps, to the lives of the other nations that share the state, will not leave each other untouched. It is this touchability that makes possible change within the nation, such that once accepted practices as slavery, wife-beating, and general gender/sex and racial oppressions might be overcome within the context of the nation. This touchability-in both of its senses-is not always as easy as those examples; such examples as circumcision and practices of animal slaughtering continue to be very difficult. Indeed, this is the major part of the cultural vitality of diaspora. The untouched and pristine are deadly fictions at best in any case.

\section{Toward the Diaspora Nation}

Abandoning thus any dualistic accounts of these domains as hierarchically distinguished, as "inner" and "outer," or "material" and "spiritual" in Christian Platonic mode, let's consider them as spatially distinct, one facing inward and one facing outward, but on the same level of materiality. There will be no more distinction-as there never was before in any case-between cultural and political. Where Chatterjee seems to be reading the "spiritual" as indeed spiritual, a realm of inner contemplation and self-knowledge, ${ }^{69} \mathrm{I}$ am going to shift it into the realm of the form of life of the nation. While for Chatterjee, the "material" is indeed material, the realm of making and doing and manipulating of objects, I am going to take it as the spaces of shared, necessarily shared, practice that enable a polity of more than one nation to coexist. ${ }^{70}$ Neither space is more material or more spiritual than the other; neither is private versus public; neither is secular versus "religious," and neither is entirely cut off from the other, or even cut off at all.

I have in previous work offered an account of diaspora that is synchronic rather than diachronic, one in which the concept of diaspora is not always founded on the presence or even imagined existence of a homeland but rather on deep connections between scattered collectives. ${ }^{71}$ In his illuminating book

\footnotetext{
${ }^{68}$ For Alexander von Humboldt, the German Volk was a Kulturvolk, not a naturally sovereign entity. Of course, he lived prior to the unification of Germany (which was never, of course, the unification of all German speakers), but neither did he conceive or dream of such a formation. I hold that one simply cannot interpret historical figures by assuming (or stipulating) that had they lived when nationstates were common that they would have joined that throng (as is done regularly for Leon Pinsker and Theodor Herzl by Zionist historians). The fact is that they didn't advocate a nation-state in the modern sense of sovereignty for one nation in one state, and they did advocate for multinational states.

${ }^{69}$ Chatterjee, The Nation and Its Fragments, 48-49.

${ }^{70}$ See the riveting discussion in Eliyahu Stern, Jewish Materialism: The Intellectual Revolution of the 1870s (New Haven, CT: Yale University Press, 2018), 18-20, on the entailments of materialism in the making of nations.

${ }^{71}$ Daniel Boyarin, A Traveling Homeland: The Babylonian Talmud as Diaspora, Divinations (Philadelphia: University of Pennsylvania Press, 2015).
} 
The Graves of Tarim, on the diaspora of Hadrami Muslims, Engseng Ho has written with respect to this diaspora:

What matters is that the dispersed understand themselves to be linked by bonds, usually those of kinship. Such bonds exist and endure, rather than atrophying, only so long as people continue to speak, sing, recite, read, write, narrate, and otherwise represent them. Representations remind us of persons and places absent from sight; they make us mindful of them. ${ }^{72}$

Paralleling Ho, I claim that there are three components that constitute the group of scattered Jewish collectives as a "diaspora," as one thing-hence the singular "the Jews"-that give "representational shape" and vitality (the opposite of atrophy) to that diaspora. They are: first, a common narrative-even if a highly contested one-of "us" (Ho's genealogy); ${ }^{73}$ second, a common language (or common languages) that differentiates us from the other folks with whom we share space, ${ }^{74}$ a language that is, itself, perfectly diasporic in its hyphenationsJudeo-German, Judeo-Tajik, Judeo-Arabic, Yinglish; and third, a set of practices shared by us across time and space. ${ }^{75}$

This is a model that is very different from the cosmopolitan, almost its opposite. The cosmopolitan is a part of no collective, by definition other than the collective of all humans, while the diasporic person is an impassioned member of at least two or sometimes more. The cosmopolitan seems always to end up with some version or another of the unmarked (universal) being whoever's in power. The diasporic is, then, taking care of (not boosting or supporting or being "proud" of $)^{76}$ your nation and working hard at some aspect(s) of its continuing cultural vitality, and at the same time, taking care of and with your compatriots in the here and now, and striving for the productive and just life for both collectives. Doubled solidarity interrupts the tunnel vision that enables lack of concern for all other people than the ethnos, while empowering at the same time passionate engagement on two fronts, the local cross-ethnic one and the

\footnotetext{
${ }^{72}$ Engseng Ho, The Graves of Tarim: Genealogy and Mobility across the Indian Ocean (Los Angeles and Berkeley: University of California Press, 2006), xxii.

${ }^{73}$ Ho makes this point by showing that within the Muslim community there are "fundamentalists" who destroy the revered graves of Hadrami Sufi saints, but what constitutes them as a "society"-I'm not entirely satisfied with that term-is that there are a set of questions, and "the answers that people develop for these questions stand within one discursive tradition in the sense that they draw on the same texts, authorities, and assumptions to a degree that is seldom acknowledged" (Ho, The Graves of Tarim, 11.)

${ }^{74}$ Northeastern Judeo Neo-Aramaic provides a wonderful model of this phenomenon:

See Oz Aloni, The Encounter of Neo-Aramaic and Modern Hebrew-the Personal Experience of a NeoAramaic Speaker, Carmilim (Haifa: University of Haifa Press, 2016), in Hebrew.

${ }^{75}$ Sometimes shared even via rejection. After all, only a Jew can define herself as one who does not keep the Shabbos.

${ }^{76}$ Too many American Jews fall into the category of those "proud ethnics" who "take pleasure in a subjective feeling of ethnic identity, but shy away from the more substantive ethnicity that demands involvement in a concrete community with organizations, mutual commitments, and some elements of constraint" (David A. Hollinger, Postethnic America: Beyond Multiculturalism [New York: Basic Books, 2005], 40).
} 
trans-local diasporic one. ${ }^{77}$ This passion provides then a base for other solidarities to emerge, but always concrete ones not abstractions. Engaging ardently with the nation, especially the trans-sovereign nation (Poland, for instance before WWI, the Jews always and everywhere) may foster deep solidarity with others when it is diasporic in this sense. ${ }^{78}$ Indeed, Césaire's "universal rich with all that is particular, rich with all the particulars there are, the deepening of each particular" requires that some collectives be deepening each particular, precisely to achieve that universal. National literatures must be studied and thought about in the context of world literature, and philology must not serve ethnocentrism or jingoism, racism, or anti-Semitism. But who's going to keep talmudic learning going if Jews don't do it (a few Oxbridge dons and Allemanic professors, viz those scholars of the Wissenschaft des Judentums who conceived as their task giving "Judaism" a "decent burial")?; who's going to continue Native American dance, language, Amazonian ontologies, if not folks from those nations (a few anthropologists?). To put it another way: Who will turn "the mass-graves of the forgotten," those very nearly buried products of historical Jewish creativity, into "enduring monuments" of those "remembered and cherished," to use Arendt's evocative language $?^{79}$ When seen from this perspective, diaspora nationalism can be grasped as the gift of any one and each collective to all of humanity.

Chatterjee is certainly correct in seeing a transformation over time in nationalist discourse from something to something else, as does Hobsbawm as well, but for many peoples, not only the Jews, that transformation was not from spiritual/cultural nationalism to political nationalism but from nationalisms of autonomy that make room for other nations to nationalisms of sovereignty that are founded on exclusion. And that distinction has made all the deadly difference. Reversing that, can we imagine "a consciousness of another kind in the present" for a future of doikayt (hereness, solidarity with others in our locale: Black Lives Matter!) and Yiddishkayt/Judaïté/Judaïtude (creative-and criticalloyalty to the diasporic culture of the Jews everywhere) synchronously, of fervid solidarity with the people and nations we live among in the territory, in the state of our dwelling, the United States for me, as well as for our national life as

\footnotetext{
${ }^{77}$ Note how this perspective tends to reduce the "paradoxical predicament" of the Jews in modernity when they are both vilified as particularists who undermine universalist claims and at the same time as "figures of deracination, abstraction," and rootlessness (Mufti, Enlightenment in the Colony, 38). Reduce but not resolve because the loyalties are, indeed, divided and in tension nonetheless.

${ }^{78}$ See too Hollinger, Postethnic America, 4-5.

${ }^{79}$ Hannah Arendt, edited, and with an introduction by Ron H. Feldman, The Jew as Pariah: Jewish Identity and Politics in the Modern Age (New York: Grove Press, 1978), 67. See Mufti, Enlightenment in the Colony, 19. We may be able to develop sufficient moral capacity to grieve all lives (see Judith Butler, Frames of War: When Is Life Grievable? [London: Verso, 2009]), but it is impossible-for me, at any rateto imagine a universal grieving for all cultural losses without particular communities to grieve them. As we are taught in the present moment (June 10,2020), "Black Lives Matter," doesn't only mean Black bodies but all the makings and doings of Black people. But note, once more, that the second that Black Lives Matter is suborned by All Lives Matter, it no longer means anything at all.
} 
members of the Jewish nation wherever and in whatever state we are ${ }^{80}$ The diaspora nation. How to achieve this, should it even be appealing in a world of both globalism and angry, violent, statist nationalisms, I leave to better minds than mine.

Author biography. Daniel Boyarin is emeritus Taubman Professor of Talmudic Culture in the Departments of Near Eastern Studies and Rhetoric at UC Berkeley. He is for 2021-2022 the Grus Professor of Jewish Law at Harvard Law School. He has devoted his career to figuring out why there are Jews, and firmly convinced that this is a good thing, has devoted and continues to devote much of his thinking to how to make that good thing valuable for all that lives as well, not only Jews. (Email: boyarin@berkeley.edu)

${ }^{80}$ This would be then a strong attempt at a corrective to the problem identified by Hollinger as a strong American constituency that "identifies with one or more diasporas and sees the United States more as a site for transnational affiliations than as an affiliation of its own" (Hollinger, Postethnic America, 15).

Cite this article: Boyarin, Daniel. 2022. "The New Jewish Question." The Cambridge Journal of Postcolonial Literary Inquiry 9, 42-66. https://doi.org/10.1017/pli.2021.29 